\title{
Pengaruh Kemandirian Belajar terhadap Kemampuan Penalaran Matematis Siswa SMP
}

\author{
Indah Mutiara Cahya ${ }^{1 \bowtie}$, Kiki Nia Sania Effendi ${ }^{2}$, Lessa Roesdiana ${ }^{3}$ \\ 1,2,3Program Studi Pendidikan Matematika, Universitas Singaperbangsa Karawang
}

\section{Info Artikel Abstract}

Sejarah Artikel:

Diterima 8 Apr 2021

Direvisi 23 Apr 2021

Disetujui 27 Apr 2021

Keywords:

Kemandirian Belajar,

Penalaran Matematis

Paper type:

Research paper

This study aims to examine whether there is an effect of independent learning on the mathematical reasoning abilities of junior high school students. This research is a quantitative study with a correlational method. The population in this study were all class VIII students at one of the public schools in Karawang Regency for the 2019/2020 academic year with 1 class being selected as the research sample, namely class VIII C. Data collection techniques were obtained using tests in the form of a description of questions regarding reasoning abilities mathematics, and non-tests in the form of independent learning questionnaires, as well as interviews conducted online. Then, the data obtained were analyzed using a simple linear regression test. Based on the results of data processing, the regression equation is obtained, namely $\mathrm{Y}=7.50+0.35 \mathrm{X}$ with a determination coefficient of $79 \%$. Thus, independent learning has a positive influence on the variable mathematical reasoning ability of students by $79 \%$, and $21 \%$ is influenced by other factors that are not included in this simple linear regression analysis. Furthermore, obtained a significance value of $0.00<0.05$, then $\mathrm{H}_{0}$ is rejected. Thus, it can be interpreted that there is a significant influence between independent learning on the mathematical reasoning abilities of junior high school students.

\begin{abstract}
Abstrak
Penelitian ini bertujuan menganalisis pengaruh kemandirian belajar terhadap kemampuan penalaran matematis siswa SMP. Penelitian ini merupakan penelitian kuantitatif dengan metode korelasional. Populasi dalam penelitian ini adalah seluruh siswa kelas VIII di salah satu Sekolah Negeri yang ada di Kabupaten Karawang Tahun Ajaran 2019/2020 dengan dipilih 1 kelas sebagai sampel penelitian yaitu kelas VIII C. Teknik pengumpulan data diperoleh dengan menggunakan tes yang berbentuk uraian soal mengenai kemampuan penalaran matematis, dan non tes yang berbentuk angket kemandirian belajar, serta wawancara yang dilakukan secara online. Kemudian, data yang diperoleh dianalisis dengan menggunakan uji regresi linear sederhana. Berdasarkan hasil pengolahan data diperoleh persamaan regresi yaitu $\mathrm{Y}=7,50+0,35 \mathrm{X}$ dengan koefisien determinasi sebesar $79 \%$. Maka, kemandirian belajar memiliki pengaruh yang positif terhadap variabel kemampuan penalaran matematis siswa sebesar $79 \%$, dan $21 \%$ lainnya dipengaruhi oleh faktor lain yang tidak termasuk dalam analisis regresi linear sederhana ini. Selanjutnya, diperoleh nilai signifikansi sebesar $0,00<$ 0,05 , maka $H_{0}$ ditolak. Dengan demikian, dapat diartikan bahwa terdapat pengaruh yang signifikan antara kemandirian belajar terhadap kemampuan penalaran matematis siswa SMP.
\end{abstract}

(C) 2021 Universitas Muria Kudus

\footnotetext{
${ }^{\square}$ Alamat korespondensi:

Program Studi Pendidikan Matematika

Fakultas Keguruan dan Ilmu Pendidikan Universitas Muria Kudus

Kampus UMK Gondangmanis, Bae Kudus Gd. L. 1t I PO. BOX 53 Kudus

Tlp (0291) 438229 ex.147 Fax. (0291) 437198

E-mail: indahmutiaracahya.13@gmail.com
}

p-ISSN 2615-4196

e-ISSN 2615-4072 
Indah Mutiara Cahya, Kiki Nia Sania Effendi, Lessa Roesdiana

Anargya: Jurnal Pendidikan Matematika, Vol. 4 No.1, April 2021

https://dx.doi.org/10.24176/anargya.v4i1.6080

\section{PENDAHULUAN}

Kurikulum 2013 (Suprihatin, Maya, \& Senjayawati, 2018), menjelaskan bahwa salah satu kompetensi inti pembelajaran matematika khususnya untuk kelas VIII dan IX SMP adalah kemampuan menalar. Hal ini berarti penalaran matematis merupakan sebuah fondasi untuk mengonstruksi pengetahuan matematika. Sejalan dengan Ball, Lewis, \& Thamel (Maimunnah \& Setyaningsih, 2017), menyatakan bahwa "mathematical reasoning is the foundation for the construction of mathematical knowledge". Depdiknas (Sofyana \& Kusuma, 2018), menyatakan bahwa materi matematika dan penalaran matematis adalah dua hal yang tidak dapat dipisahkan, yaitu materi matematika dipahami melalui penalaran, dan penalaran dipahami dan dilatih melalui belajar matematika. Sehingga kemampuan penalaran matematis merupakan kemampuan yang sangat penting dan pembelajaran matematika di sekolah salah satunya bertujuan agar siswa memiliki kemampuan penalaran matematis.

Menurut Sumarmo (Rosita, 2014), kemampuan penalaran terbagi menjadi dua macam, yaitu penalaran induktif dan penalaran deduktif. Penalaran induktif adalah penarikan kesimpulan yang bersifat umum atau khusus berdasarkan data yang teramati dengan nilai kebenaran yang dapat bersifat benar atau salah. Sedangkan menurut Soedjadi (Kusuma, 2016), menjelaskan bahwa penalaran deduktif adalah penalaran yang berpangkal dari hal yang bersifat umum menuju hal yang bersifat khusus. Adapun Sumartini (2015), mengemukakan bahwa penalaran matematis adalah suatu proses berpikir dalam menentukan sebuah argumen matematika benar atau salah yang selanjutnya digunakan untuk membuat suatu argumen matematika baru. Sehingga dapat disimpulkan, kemampuan penalaran matematis merupakan suatu kemampuan berfikir seseorang secara logis untuk menarik sebuah kesimpulan dalam pembelajaran matematika baik yang bersifat umum maupun khusus.

Pentingnya kemampuan penalaran matematis dalam pembelajaran matematika salah satunya yaitu memudahkan siswa dalam memecahkan atau menyelesaikan permasalahan yang dapat dikatakan rumit. Faktanya kemampuan penalaran matematis siswa di lapangan masih dikatakan rendah. Rendahnya kemampuan penalaran matematis siswa dibuktikan dengan hasil penelitian yang telah dilakukan oleh Cahya \& Warmi (2020), menunjukan bahwa kemampuan penalaran matematis siswa memiliki tingkat kategori rendah dengan persentase sebesar 49,41\%. Faktor yang dapat mempengaruhi rendahnya kemampuan penalaran matematis siswa selain dari faktor internal yang timbul dalam diri siswa itu sendiri, salah satunya yaitu ada pada kemandirian belajar. Sejalan dengan Fajriyah, et al. (2019), dimana semakin tinggi kemandirian belajar yang dimiliki siswa, maka akan semakin tinggi pula kemampuan penalaran matematis siswa tersebut. Menurut Suparno (Tujuh, 2019), mengemukakan bahwa self regulated learning (kemandirian) penting dalam belajar karena dengan adanya kemandirian belajar, keberhasilan dan prestasi belajar akan mudah diperoleh, karena kemandirian dalam belajar merupakan suatu langkah yang efektif dan efisien dalam memaksimalkan kemampuan siswa tanpa harus bergantung pada guru, sehingga proses belajar mengajar akan lebih optimal. Peranan guru lebih banyak menempatkan diri sebagai pembimbing/pemimpin belajar dan fasilitator belajar (Effendi \& Aini, 2018).

Kemandirian belajar merupakan kemampuan dalam belajar yang didasarkan pada rasa tanggung jawab, percaya diri, inisiatif, dan motivasi sendiri dengan atau tanpa bantuan orang lain yang relatif untuk menguasai kompetensi tertentu, baik dalam aspek pengetahuan, keterampilan maupun sikap yang dapat digunakan untuk memecahkan masalah belajarnya Nurhayati (Marfuati \& Suharto, 2019). Sedangkan Bandura (Anggita, 2019), menjelaskan bahwa kemandirian merupakan kemampuan memantau perilaku sendiri, serta kerja keras personalitas manusia. Sehingga, kemandirian belajar merupakan kemampuan siswa dalam belajar yang didasarkan atas kemauan diri sendiri tanpa adanya bantuan dari orang lain untuk menguasai kompetensi tertentu, baik dalam aspek pengetahuan, keterampilan maupun sikap sehingga dapat digunakan untuk memecahkan berbagai masalah dalam proses pembelajarannya.

Pannen, Mustafa, \& Sekarwinahyu (Nuridawani, Munzir, \& Saiman, 2015), menjelaskan bahwa ciri utama dalam belajar mandiri bukanlah ketiadaan guru atau teman sesama siswa, atau tidak adanya pertemuan tatap muka di kelas, melainkan adanya pengembangan kemampuan siswa untuk melakukan proses belajar yang tidak tergantung pada faktor guru, teman, kelas dan lain-lain. Tingkat kemandirian belajar siswa dapat ditentukan berdasarkan 
seberapa besar inisiatif dan tanggungjawab siswa untuk berperan aktif dalam hal perencanaan belajar, proses belajar, maupun evaluasi belajar. Semakin besar peran aktif siswa dalam berbagai kegiatan tersebut, mengindikasikan bahwa siswa tersebut memiliki tingkat kemandirian belajar yang tinggi. Berdasarkan latar belakang di atas, tujuan penelitian ini yaitu untuk menganalisis pengaruh kemandirian belajar terhadap kemampuan penalaran matematis siswa SMP.

\section{METODE PENELITIAN}

Penelitian ini merupakan penelitian kuantitatif dengan metode korelasional. Menurut Ary, dkk (2010), menjelaskan bahwa correlational research (penelitian korelasional) merupakan penelitian non-eksperimen yang mempelajari arah dan hubungan antar variabel. Populasi dalam penelitian ini adalah seluruh siswa kelas VIII di salah satu Sekolah Negeri yang ada di Kabupaten Karawang Tahun Ajaran 2019/2020. Teknik pengambilan sampel yang digunakan dalam penelitian ini yaitu teknik probability sampling dengan jenis cluster random sampling. Menurut Azwar (Sari, 2014), cluster random sampling adalah melakukan randomisasi terhadap kelompok, bukan terhadap subjek secara individual. Maka, pengambilan sampel berdasarkan daerah populasi yang telah ditentukan yakni dipilih 1 kelas sebagai sampel penelitian yaitu kelas VIII C.

Teknik pengumpulan data diperoleh dengan menggunakan tes yang berbentuk uraian soal mengenai kemampuan penalaran matematis, dan non tes yang berbentuk angket kemandirian belajar secara online dengan berbantuan aplikasi google form, serta wawancara yang mengacu kepada aspek afektif (yang berkaitan dengan angket kemandirian belajar) dan kognitif (yang berkaitan dengan soal tes kemampuan penalaran matematis) dengan berbantuan aplikasi whatsapp. Kemudian, data dianalisis dengan menggunakan uji regresi linear sederhana untuk mengetahui ada tidaknya pengaruh kemandirian belajar terhadap kemampuan penalaran matematis siswa SMP. Adapun hipotesis yang digunakan pada penelitian ini yaitu:

$\mathrm{H}_{0}$ : Tidak terdapat pengaruh kemandirian belajar terhadap kemampuan penalaran matematis siswa SMP.

$\mathrm{H}_{1}$ : Terdapat pengaruh kemandirian belajar terhadap kemampuan penalaran matematis siswa SMP.
Kriteria pengujian hipotesis yaitu sebagai berikut:

1. Jika nilai signifikansi $(\mathrm{sig})<0,05$ maka $\mathrm{H}_{0}$ diterima.

2. Jika nilai signifikansi (sig) $<0,05$ maka $\mathrm{H}_{0}$ ditolak.

\section{HASIL DAN PEMBAHASAN}

Berdasarkan hasil penyebaran angket kemandirian belajar siswa secara online dengan berbantuan aplikasi google form, kemandirian belajar siswa SMPN 2 Tempuran berada pada kategori baik. Adapun kategori setiap indikator yaitu sebagai berikut:

Tabel 1. Kategori Kemandirian Belajar

\begin{tabular}{lcc}
\hline \multicolumn{2}{c}{ Kemandirian Belajar } \\
\hline $\begin{array}{l}\text { Inisiatif dan motivasi } \\
\text { belajar intrinsik }\end{array}$ & Persentase & Kategori \\
\hline $\begin{array}{l}\text { Kebiasaan mendiagnosa } \\
\text { kebutuhan belajar }\end{array}$ & $71,05 \%$ & Baik \\
\hline $\begin{array}{l}\text { Kebiasaan menetapkan } \\
\text { tujuan/target belajar }\end{array}$ & $68,42 \%$ & Baik \\
$\begin{array}{l}\text { Memonitor, mengatur } \\
\text { dan mengontrol belajar }\end{array}$ & $64,47 \%$ & Baik \\
$\begin{array}{l}\text { Memandang kesulitan } \\
\text { sebagai tantangan }\end{array}$ & $65,79 \%$ & Baik \\
$\begin{array}{l}\text { Memanfaatkan dan } \\
\text { mencari sumber yang } \\
\text { relevan }\end{array}$ & $71,04 \%$ & Baik \\
$\begin{array}{l}\text { Memilih dan } \\
\text { menerapkan strategi } \\
\text { belajar }\end{array}$ & $63,16 \%$ & Baik \\
$\begin{array}{l}\text { Mengevaluasi proses } \\
\text { dan hasil belajar }\end{array}$ & $71,06 \%$ & Baik \\
$\begin{array}{l}\text { Self efficaci } \text { konsep } \\
\text { diri) }\end{array}$ & $68,42 \%$ & Baik \\
\hline
\end{tabular}

Hasil penyebaran tes kemampuan penalaran matematis secara online dengan berbantuan aplikasi google form, diperoleh nilai rata-rata sebesar 60,07 , sedangkan nilai kriteria ketuntasan minimal (KKM) di sekolah tersebut yaitu sebesar 60. Maka, nilai rata-rata kemampuan penalaran matematis siswa berada di atas KKM yaitu sebesar 60,07. Jadi, kemampuan penalaran matematis siswa kelas VIII di SMPN 2 Tempuran dapat dikatakan baik.

Data yang diperoleh akan dirubah terlebih dahulu dengan menggunakan methode succesive interval (MSI) dengan berbantuan Microsoft Excel 2013 yang telah dilengkapi dengan aplikasi Add-in yang bertujuan untuk mengubah data ordinal menjadi data interval. Sebelum data 
dianalisis akan dilakukan uji prasyarat terlebih dahulu yaitu uji normalitas yang bertujuan untuk mengetahui apakah data tersebut berasal dari populasi yang berdistibusi normal atau tidak. Data dikatakan normal jika signifikansinya lebih dari 0,05 (Priyanto dalam Amaliah, 2017). Karena sampel dalam penelitian ini kurang dari 50, maka uji normalitas dalam penelitian ini menggunakan uji Shapiro-Wilk dengan berbantuan Software IBM SPSS 22 for windows diperoleh nilai signifikansi sebesar 0,428 >0,05 maka $\mathrm{H}_{0}$ diterima, artinya data berasal dari populasi yang berdistribusi normal. Selanjutnya, data akan dianalisis menggunakan uji regresi linear sederhana dengan berbantuan Software IBM SPSS 22 for windows. Adapun hasilnya yaitu sebagai berikut:

Tabel 2. Coefficients

\begin{tabular}{|c|c|c|c|c|c|}
\hline \multirow[b]{2}{*}{ Model } & \multicolumn{2}{|c|}{$\begin{array}{l}\text { Unstandardized } \\
\text { Coefficients }\end{array}$} & \multirow{2}{*}{$\begin{array}{c}\text { Standardized } \\
\text { Coefficients } \\
\text { Beta } \\
\end{array}$} & \multirow[b]{2}{*}{ t } & \multirow[b]{2}{*}{ Sig. } \\
\hline & B & $\begin{array}{l}\text { Std. } \\
\text { Error }\end{array}$ & & & \\
\hline (Cons & & & & & \\
\hline $\operatorname{tant})$ & 7,50 & 3,31 & & 2,26 & 0,03 \\
\hline $\mathrm{X}$ & 0,35 & 0,03 & 0,88 & 11,30 & 0,00 \\
\hline
\end{tabular}

Berdasarkan Tabel 2 di atas, diperoleh persamaan regresi linear sederhana yaitu $\mathrm{Y}=$ $7,50+0,35 \mathrm{X}$, dapat diartikan bahwa koefisien regresi untuk konstanta sebesar 7,50 menunjukan bahwa jika variabel kemandirian belajar bernilai nol atau tetap, maka akan meningkatkan kemampuan penalaran matematis siswa sebesar 7,50 satuan atau sebesar $750 \%$. Adapun variabel kemandirian belajar sebesar 0,35, menunjukan bahwa jika variabel kemandirian belajar meningkat 1 satuan, maka akan meningkatkan kemampuan penalaran matematis siswa sebesar $35 \%$. Kemudian, terdapat nilai signifikansi sebesar $0,00<0,05$ maka $\mathrm{H}_{0}$ ditolak artinya terdapat pengaruh kemandirian belajar terhadap kemampuan penalaran matematis siswa SMP. Adapun besarnya pengaruh kemandirian belajar terhadap kemampuan penalaran matematis siswa SMP dapat dilihat pada Tabel 3 berikut ini:

Tabel 3. Model Summary

\begin{tabular}{lcrrc}
\hline & & $\mathrm{R}$ & Adjusted R & td. Error of The \\
Model & $\mathrm{R}$ & Square & Square & Estimate \\
1 & $0,889^{\mathrm{a}}$ & 0,790 & 0,789 & 3,771 \\
\hline
\end{tabular}

Berdasarkan Tabel 3 di atas, diperoleh nilai R Square sebesar 0,790. Maka, dapat disimpulkan bahwa kemandirian belajar memiliki pengaruh yang positif terhadap kemampuan penalaran matematis siswa sebesar $79 \%$, dan $21 \%$ lainnya dipengaruhi oleh faktor atau variabel lain yang tidak termasuk kedalam analisis regresi linear sederhana ini. Berikut analisis jawaban siswa pada tes kemampuan penalaran matematis dengan indikator menarik kesimpulan dari pernyataan.

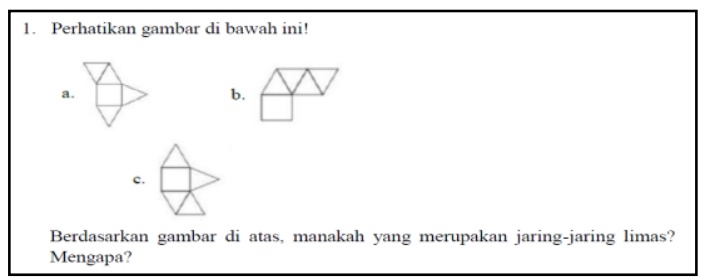

Gambar 1. Soal Nomor 1

Adapun jawaban serta solusi yang digunakan oleh siswa dalam menjawab soal nomor 1 dapat dilihat pada Gambar 2. Jawaban yang diberikan siswa diperkuat dengan penjelasan siswa pada kegiatan wawancara, dan tercapai atau tidaknya indikator kemampuan penalaran matematis pada soal nomor 1 akan dilihat berdasarkan jawaban siswa dan hasil wawancara.

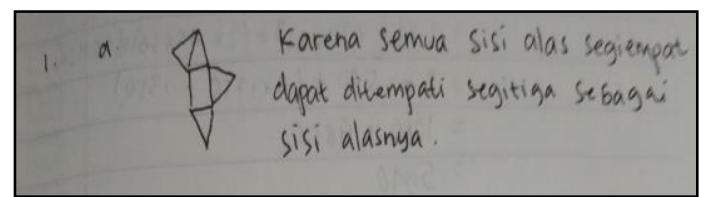

Gambar 2. Jawaban Siswa Pada Soal Nomor 1

Berdasarkan Gambar 2 di atas, siswa mampu menjawab soal dengan benar dan mampu mengajukan dugaan yang tepat terhadap apa yang ditanyakan dalam soal tersebut. Hal ini dibuktikan dengan hasil wawancara, dimana ketika siswa ditanya perihal apa yang ditanyakan dalam soal siswa mampu menjawabnya dengan benar dan yakin terhadap jawabannya serta dapat memberikan alasan yang tepat terhadap jawaban yang siswa lontarkan. Dengan demikian, kemampuan penalaran matematis siswa pada indikator mengajukan dugaan sudah tercapai. Sejalan dengan Mualifah (Ardiyanti, Sutriyono, \& Pratama, 2019), dimana siswa yang berkemampuan matematika tinggi berhasil melakukan dugaan dengan dapat menyebutkan informasi-informasi yang tersedia dalam soal.

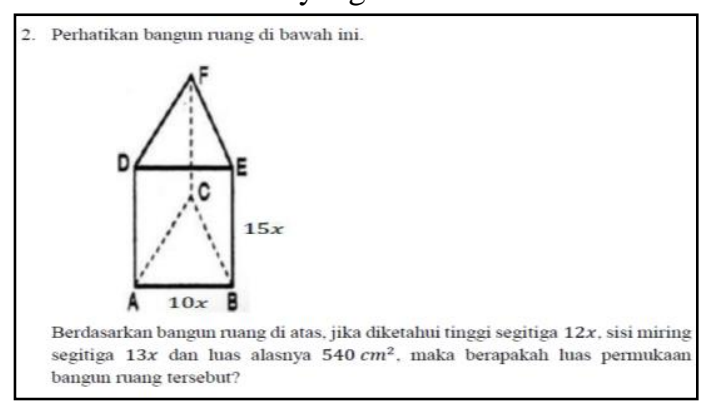




\section{Gambar 3. Soal Nomor 2}

Adapun jawaban serta solusi yang digunakan oleh siswa dalam menjawab soal nomor 2 dapat dilihat pada Gambar 4. Jawaban yang diberikan siswa diperkuat dengan penjelasan siswa pada kegiatan wawancara, dan tercapai atau tidaknya indikator kemampuan penalaran matematis pada soal nomor 2 akan dilihat berdasarkan jawaban siswa dan hasil wawancara.

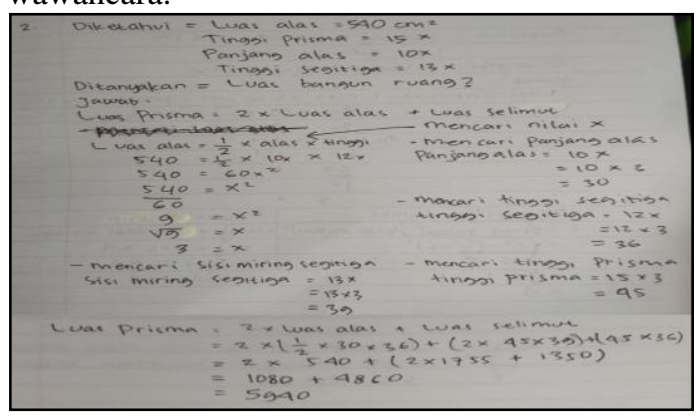

Gambar 4. Jawaban Siswa Pada Soal Nomor

\section{2}

Berdasarkan Gambar 4 di atas, siswa mampu menuliskan apa yang diketahui dan ditanyakan pada soal tersebut, serta siswa menggunakan solusi dan melakukan manipulasi yang tepat dalam menjawab soal tersebut sehingga siswa dapat menyelesaikan soal dengan benar. Hal ini dibuktikan dengan hasil wawancara, dimana ketika siswa ditanya sudah paham atau belum mengenai soal tersebut dan siswa menjawab sudah dengan yakin dan percaya diri, sehingga ketika siswa diminta menjelaskan kembali cara untuk menyelesaikan soal tersebut siswa mampu menjawabnya dengan langkahlangkah yang tepat. Dengan demikian, kemampuan penalaran matematis siswa pada indikator melakukan manipulasi matematika sudah tercapai. Sejalan dengan Nafi'ah (Ardiyanti, Sutriyono, \& Pratama, 2019), dimana siswa yang mampu melakukan manipulasi dapat dilihat dari cara siswa dalam menyelesaikan masalah.

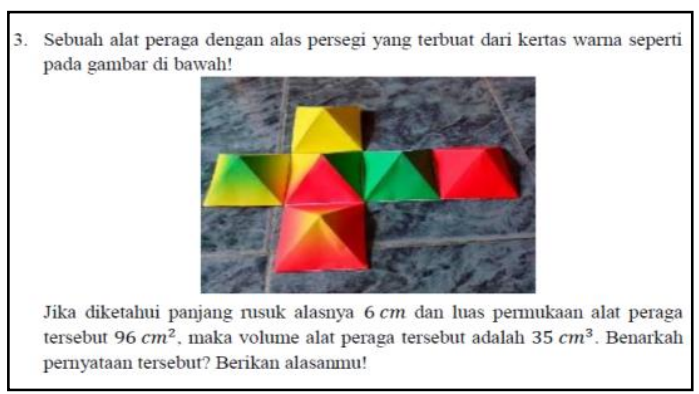

Gambar 5. Soal Nomor 3
Adapun jawaban serta solusi yang digunakan oleh siswa dalam menjawab soal nomor 3 dapat dilihat pada Gambar 6. Jawaban yang diberikan siswa diperkuat dengan penjelasan siswa pada kegiatan wawancara, dan tercapai atau tidaknya indikator kemampuan penalaran matematis pada soal nomor 3 akan dilihat berdasarkan jawaban siswa dan hasil wawancara.

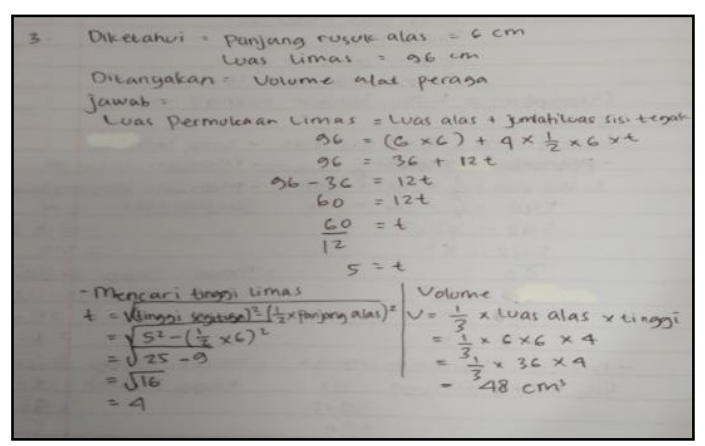

Gambar 6. Jawaban Siswa Pada Soal Nomor 3

Berdasarkan Gambar 6 di atas, siswa mampu menuliskan apa yang diketahui dan ditanyakan pada soal tersebut, serta siswa mampu menyusun bukti dan solusi yang tepat dalam menjawab soal tersebut sehingga siswa dapat menjawab soal dengan benar. Akan tetapi, siswa tersebut tidak memberikan alasan terhadap solusi yang ditulisnya. Hal ini dibuktikan dengan hasil wawancara, dimana ketika siswa ditanya sudah paham atau belum mengenai soal tersebut dan siswa menjawab sudah dan yakin, sehingga ketika siswa diminta menjelaskan kembali cara untuk menyelesaikan soal tersebut siswa mampu menjawabnya dengan langkah-langkah yang tepat. Kemudian ketika siswa diminta untuk memberikan alasan terhadap jawaban yang dulisnya siswa tersebut mampu memberikan alasan yang tepat. Dengan demikian, kemampuan penalaran matematis siswa pada indikator menarik kesimpulan, menyusun bukti, memberi alasan terhadap kebenaran solusi sudah tercapai. Sejalan dengan Nugraheni (Ardiyanti, Sutriyono, \& Pratama, 2019), dimana siswa yang memiliki kemampuan matematika sedang dapat menarik kesimpulan, menyusun bukti, dan memberikan alasan dari langkah yang digunakan dalam menyelesaikan masalah.

4. Terdapat sebuah bangun nuang yang memiliki alas dan tutup berbentuk segitiga
sama kaki dengan panjang alas segitiga $5 \mathrm{~cm}$ dan tinggi $12 \mathrm{~cm}$. Jika tinggi
bangun nuang tersebut $15 \mathrm{~cm}$, maka volumenya adalah $320 \mathrm{~cm}^{3}$. Benarkah
pernyataan tersebut? Jika benar, jelaskan! Jika salah, mengapa?




\section{Gambar 7. Soal Nomor 4}

Adapun jawaban serta solusi yang digunakan oleh siswa dalam menjawab soal nomor 4 dapat dilihat pada Gambar 8. Jawaban yang diberikan siswa diperkuat dengan penjelasan siswa pada kegiatan wawancara, dan tercapai atau tidaknya indikator kemampuan penalaran matematis pada soal nomor 4 akan dilihat berdasarkan jawaban siswa dan hasil wawancara.

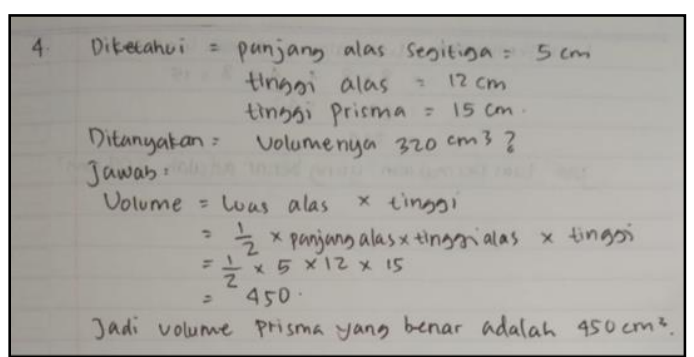

Gambar 8. Jawaban Siswa Pada Soal Nomor

$$
4
$$

Berdasarkan Gambar 2 di atas, siswa mampu menuliskan apa yang diketahui dan ditanyakan pada soal tersebut, serta siswa mampu menjawab soal dengan langkah-langkah yang tepat, sehingga siswa mampu menarik kesimpulan yang tepat dari soal dan jawaban yang ditulisnya. Hal ini dibuktikan dengan hasil wawancara, dimana ketika siswa ditanya sudah paham atau belum mengenai soal tersebut kemudian dengan yakinnya siswa menjawab sudah paham, sehingga ketika siswa diminta menjelaskan kembali cara untuk menyelesaikan soal tersebut siswa mampu menjawabnya dengan langkah-langkah yang tepat, serta ketika siswa diminta untuk menarik kesimpulan terhadap jawaban yang dulisnya siswa tersebut mampu memberikan kesimpulan yang tepat. Dengan demikian, kemampuan penalaran matematis siswa pada indikator menarik kesimpulan dari pernyataan sudah tercapai. Sejalan dengan Melin (Ardiyanti, Sutriyono, \& Pratama, 2019), bahwa subjek berkemampuan matematika sedang mampu membuat kesimpulan berdasarkan soal dan jawaban yang diperolehnya.

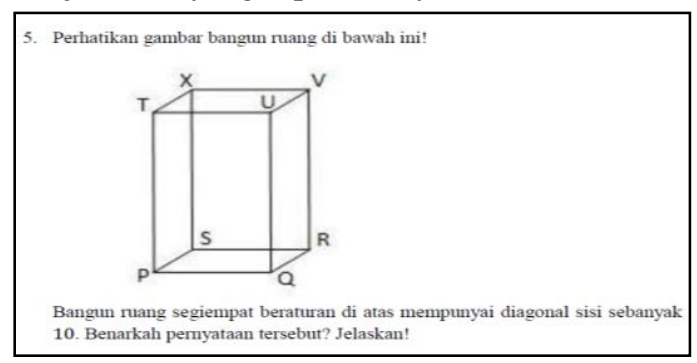

\section{Gambar 9. Soal Nomor 5}

Adapun jawaban serta solusi yang digunakan oleh siswa dalam menjawab soal nomor 5 dapat dilihat pada Gambar 10. Jawaban yang diberikan siswa diperkuat dengan penjelasan siswa pada kegiatan wawancara, dan tercapai atau tidaknya indikator kemampuan penalaran matematis pada soal nomor 5 akan dilihat berdasarkan jawaban siswa dan hasil wawancara.

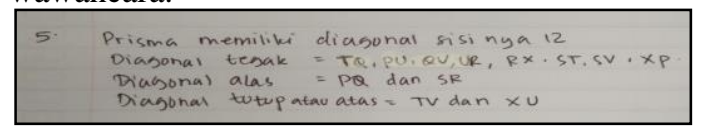

Gambar 10. Jawaban Siswa Pada Soal Nomor 5

Berdasarkan Gambar 10 di atas, siswa mampu menjawab soal dengan tepat, serta mampu memberikan bukti terhadap jawaban yang ditulisnya. Hal ini dibuktikan dengan hasil wawancara, dimana ketika siswa diminta untuk menyebutkan kembali apa saja diagonal sisi dari prisma tersebut, siswa mampu menyebutkannya dengan benar. Dengan demikian, kemampuan penalaran matematis siswa pada indikator memeriksa kesahihan suatu argumen sudah tercapai. Sejalan dengan Wahyuni, dkk (2019), dimana siswa dengan kemampuan penalaran kategori tinggi telah mampu menyelesaikan sebagian besar soal yang diberikan, serta siswa lebih cepat memahami apa yang dimaksud oleh soal dan apa yang ditayakan.

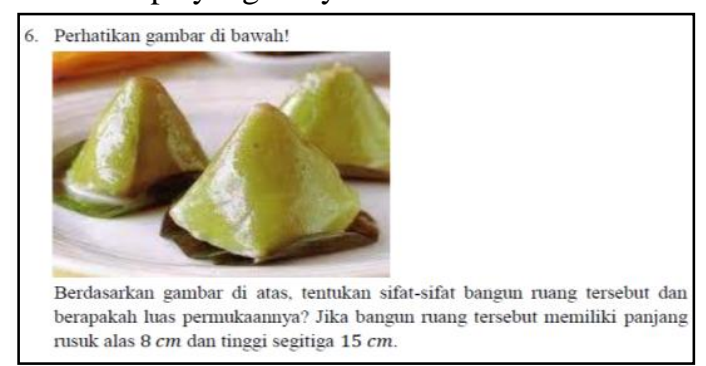

\section{Gambar 11. Soal Nomor 6}

Adapun jawaban serta solusi yang digunakan oleh siswa dalam menjawab soal nomor 6 dapat dilihat pada Gambar 12. Jawaban yang diberikan siswa diperkuat dengan penjelasan siswa pada kegiatan wawancara, dan tercapai atau tidaknya indikator kemampuan penalaran matematis pada soal nomor 6 akan dilihat berdasarkan jawaban siswa dan hasil wawancara.

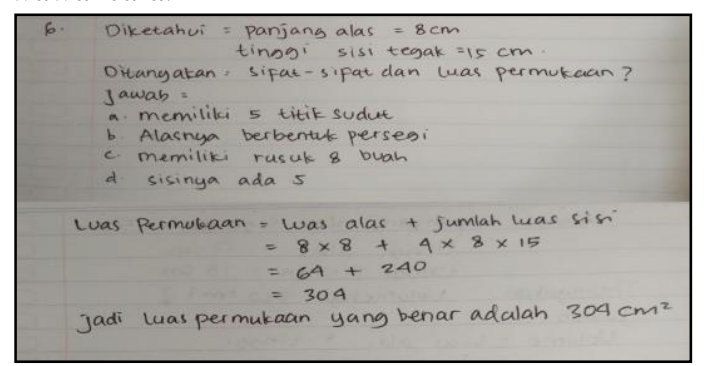




\section{Gambar 12. Jawaban Siswa Pada Soal Nomor 6}

Berdasarkan gambar tersebut siswa mampu menuliskan apa yang diketahui dan ditanyakan pada soal tersebut, dan siswa mampu menuliskan sifat-sifat dari bangun ruang tersebut, serta dapat menjawab soal dengan menuliskan langkah-langkah yang tepat dan menuliskan kesimpulan yang tepat terhadap jawaban yang ditulisnya. Hal ini dibuktikan dengan hasil wawancara, dimana ketika siswa diminta untuk menyebutkan kembali apa saja yang termasuk sifat-sifat dari bangun ruang tersebut, siswa mampu menyebutkannya dengan benar, serta ketika siswa diminta untuk menjelaskan langkahlangkah dalam menyelesaikan soal tersebut siswa sudah mampu menjelaskannya dengan langkahlangkah dan jawaban yang benar. Dengan demikian, kemampuan penalaran matematis siswa pada indikator menentukan pola atau sifat dari gejela matematika untuk membuat generalisasi sudah tercapai. Sejalan dengan Wahyuni, dkk (2019), walaupun soal yang diberikan tersebut bukan dalam soal biasa, namun siswa dengan kategori tinggi tetap bisa mengerjakan soal dengan baik.

Terdapat beberapa faktor lain sebesar $21 \%$ yang dapat mempengaruhi kemampuan penalaran matematis siswa seperti faktor afektif dan kognitif. Faktor afektif yang dapat mempengaruhi kemampuan penalaran matematis selain kemandirian belajar yaitu ada pada kecemasan belajar. Hal ini dibuktikan dengan hasil wawancara, dimana ketika siswa diminta untuk menjelaskan kembali cara untuk menyelesaikan soal nomor 2, siswa menjawabnya dengan waktu yang cukup lama dan ragu-ragu sedangkan siswa tersebut mampu menjawab soal dengan langkah-langkah yang tepat. Kemudian, pada saat ditanya mengapa menjawabnya lama, siswa tersebut menjawab takut jawaban yang dia jelaskan tidak tepat serta takut dihukum karena salah menjawab. Sejalan dengan hasil penelitian Munasiah (2015), kecemasan belajar berpengaruh langsung yang negatif terhadap kemampuan penalaran matematika, dan apabila kemampuan penalaran matematika ingin ditingkatkan secara optimal, maka perlu mengurangi atau meminimalisir adanya perasaan cemas, khawatir, atau takut terhadap pelajaran matematika saat belajar.

Adapun faktor kognitif yang dapat mempengaruhi kemampuan penalaran matematis salah satunya yaitu penguasaan konsep matematika. Hal ini dibuktikan dengan hasil wawancara, dimana ketika siswa diminta untuk menjelaskan kembali langkah-langkah dalam menjawab soal nomor 3 siswa tersebut tidak mampu menjawabnya dengan tepat. Kemudian, ketika ditanya mengapa jawabannya tidak tepat, siswa tersebut menyadari atau mengakui bahwa dirinya belum menguasai materi atau belum menguasai konsep dari materi tersebut. Sejalan dengan hasil penelitian Akuba, Purnamasari, \& Firdaus (2020), bahwa terdapat pengaruh langsung positif antara kemampuan penalaran matematis terhadap tingkat penguasaan konsep matematika, artinya semakin terampil siswa dalam penalaran matematis maka semakin tinggi tingkat penguasaan konsep siswa tersebut di dalam pelajaran matematika, dan sebaliknya, jika kemampuan penalaran matematis siswa rendah maka tingkat penguasaan konsep juga rendah.

\section{KESIMPULAN}

Berdasarkan hasil analisis data dan pembahasan, dapat dilihat dari hasil uji statistika t dimana diperoleh nilai signifikansi $0,000<$ 0,05, maka $H_{0}$ ditolak. Kemudian dari hasil uji regresi linear sederhana diperoleh persamaan yaitu $Y=7,508+0,357 X$ dan koefisien determinasi sebesar 79\%. Sehingga, dapat disimpulkan bahwa terdapat pengaruh kemandirian belajar terhadap kemampuan penalaran matematis siswa SMP, dan kemandirian belajar memiliki pengaruh yang positif terhadap variabel kemampuan penalaran matematis siswa sebesar 79\%. Adapun $21 \%$ lainnya dipengaruhi oleh faktor atau variabel lain yang tidak diketahui serta tidak termasuk dalam analisis regresi linear sederhana ini.

\section{DAFTAR PUSTAKA}

Akuba, S. F., Purnamasari, D., \& Firdaus, R. 2020. Pengaruh Kemampuan Penalaran, Efikasi Diri dan Kemampuan Memecahkan Masalah Terhadap Penguasaan Konsep matematika. JNPM (Jurnal Nasional Pendidikan Matematika), 4(1).

Amaliah, R. 2017. Hasil Belajar Biologi Materi Sistem Gerak dengan Menerapkan Model Pembelajaran Kooperatif Tipe Rotating Trio Exchange (RTE) Pada 
Siswa Kelas XI SMAN 4 Bantimurung. Jurnal Dinamika, 8(01).

Anggita, S. 2019. Deskripsi Kemampuan Berpikir Tingkat Tinggi Siswa SMP Negeri 1 Kersana dalam Menyelesaikan Masalah Open Ended Ditinjau dari Self Regulated Learning (SKRIPSI). Purwokerto: Universitas Muhammadiyah Purwokerto. Retrieved 04 Juni Kamis, 2020, from https://www.google.com/url?sa=t\&rct=j $\& \mathrm{q}=\&$ esrc $=$ s\& source $=$ web $\& \mathrm{~cd}=\& \mathrm{cad}=\mathrm{r}$ ja\&uact $=8 \&$ ved $=2$ ahUKEwiY9s7g9ZP wAhUIILcAHdOJDBQQFjAAegQIAh AD\&url=http $\% 3 \mathrm{~A} \% 2 \mathrm{~F} \% 2$ Frepository.u mp.ac.id\%2F9358\%2F\&usg=AOvVaw 2TZ3S1AFDQHT2y06RuwABS

Ardiyanti, E., Sutriyono, \& Pratama, F. W. 2019. Deskripsi Kemampuan Penalaran Siswa Dalam Pemecahan Masalah Matematika Pada Materi Aritmatika Sosial. Jurnal Cendekia: Pendidikan Indonesia, 3(1).

Ary, D., Jacobs, L. C., Sorensen, C., \& Razavieh, A. 2010. Introduction to Research in Education. USA: Wadsworth.

Cahya, I. M., \& Warmi, A. 2020. Analisis Tingkat Kemampuan Penalaran Matematis Siswa SMP Pada Materi Relasi dan Fungsi. Prosiding Seminar Nasional Matematika dan Pendidikan Matematika, 2(3). Retrieved 08 Januari Rabu, 2020, from https://journal.unsika.ac.id/index.php/se siomadika/article/view/2656

Effendi, K. N., \& Aini, I. N. 2018. Pelatihan Penyusunan Lembar Kerja Siswa (LKS) Bagi Guru Matematika SMP di Telukjambe, Karawang. Jurnal Pengabdian Pada Masyarakat, 3(1).

Fajriyah, L., Nugraha, Y., Akbar, P., \& Bernard, M. 2019. Pengaruh Kemandirian Belajar Siswa SMP Terhadap Kemampuan Penalaran Matematis. Jurnal On Education, 1(2).

Kusuma, R. R. 2016. Analisis Kemampuan Penalaran Matematis dan Kecerdasan Emosional Pada Siswa Kelas VIII SMP Negeri 2 Sumbang (SKRIPSI). Purwokerto: Universitas Muhammadiyah Purwokerto. Retrieved 09 Maret Senin, 2020, from https://docplayer.info/35571437Analisis-kemampuan-penalaranmatematis-dan-kecerdasan-emosional- pada-siswa-kelas-viii-smp-negeri-2sumbang.html

Maimunnah, T., \& Setyaningsih, N. 2017. Peningkatan Penalaran Matematika Melalui Strategi Think Fair Share Berbasis Problem Based Learning. Seminar Nasional Pendidikan Matematika.

Marfuati, R., \& Suharto, T. N. 2019. Hubungan Konsep Diri dan Persepsi Pola Asuh Authotitative dengan Kemandirian Belajar pada Siswa. Jurnal Keluarga, $5(1)$.

Munasiah. 2015. Pengaruh Kecemasan Belajar dan Pemahaman Konsep Matematika Siswa Terhadap Kemampuan Penalaran Matematika. Jurnal Formatif, 5(3).

Nuridawani, Munzir, S., \& Saiman. 2015. Peningkatan Kemampuan Penalaran Matematis dan Kemandirian Belajar Siswa Madrasah Tsanawiyah (MTs) melalui Pendekatan Contextual Teaching and Learning (CTL). Jurnal Didaktik Matematika, 2(2).

Rosita, C. D. 2014. Kemampuan Penalaran dan Komunikasi Matematis: Apa, Mengapa dan Bagaimana Ditingkatkan Pada Mahasiswa. Jurnal Euclid, 1(1).

Sari, D. (2014). Hubungan Antara Dukungan Sosial Dengan Hardiness Pada Remaja Yang Tinggal Di Panti Asuhan (SKRIPSI). Riau: Universitas Islam Negeri Sultan Sarif Kasim. Retrieved 07 April Selasa, 2020, from http://repository.uin-suska.ac.id/6201/

Sofyana, U. M., \& Kusuma, A. B. 2018. Upaya Meningkatkan Kemampuan Penalaran Matematis Siswa Menggunakan Pembelajaran Generatif Pada Kelas VII SMP Muhammadiyah Kaliwiro. KONTINU:Jurnal Penelitian Didaktik Matematika, 2(2).

Sumartini, T. S. 2015. Peningkatan kemampuan penalaran Matematis Siswa Melalui Pembelajaran Berbasis Masalah. Jurnal Pendidikan Matematika, 5(1).

Suprihatin, T., Maya, R., \& Senjayawati, E. 2018. Analisis Kemampuan Penalaran Matematis Siswa SMP Pada Materi Segitiga dan Segiempat. Jurnal Kajian Pembelajaran Matematika, 2(1).

Tujuh, S. H. 2019. Pentingnya Ganjaran dan Hukuman terhadap Perilaku Kemandirian Siswa dalam Pendidikan 
Indah Mutiara Cahya, Kiki Nia Sania Effendi, Lessa Roesdiana

Anargya: Jurnal Pendidikan Matematika, Vol. 4 No.1, April 2021 https://dx.doi.org/10.24176/anargya.v4i1.6080

Agama Islam. Tarbawy: Jurnal

Pendidikan Islam, 6(1).

Wahyuni, Z., Roza, Y., \& Maimunah. 2019.

Analisis Kemampuan Penalaran

Matematika Siswa Kelas X Pada Materi

Dimensi Tiga. Jurnal Ilmiah

Pendidikan Matematika Al-Qalasadi, 3(1). 